\title{
The Paradigmatic Group of the Borrowings in the Modern Albanian Language from Greek
}

\author{
PhD. Sofia Delijorgji \\ PhD. Isida Foci \\ Greek Language Branch, Slavonic and Balkan Languages Department, Foreign Languages Faculty \\ University of Tirana
}

\section{Doi:10.5901/mjss.2014.v5n27p1628}

\section{Abstract}

Borrowing is one of the commonly known language processes and phenomena. It is determined by intra- and extralinguistic factors. Lexical and semantic subsystem is more open to this process, and word is the language unit which is borrowed easier and faster. This is obvious even in the borrowings of the Albanian language from Greek. Borrowings enter the language in different ways, forms and at different times. They show that nations which have developed linguistic exchanges have had common borders or historical, cultural or economic relations. The process of borrowing contributes to the enrichment of a certain language. Anyway, unlimited and uncontrolled borrowing turns into a harmful phenomenon for our language, especially when the discourse or the lexical layer of the general use is filled with foreign words.

Keywords: borrowings, word-formation paradigmatic groups, lexis, standard language

In our opinion the borrowing relations and the lexical-semantic interferences are directly connected to the language relativism thesis. R. Hudson explains that "an aspect of relativism can be easily demonstrated, because in some languages we cannot individualize some units, which apparently express some meanings that cannot be expressed in some other languages. This can be noticed during the translation challenges from one language to another, which are connected to different cultures and consequently provide words for a wide variety of customs, objects, institutions and so on." ${ }^{1}$

Borrowing is one of the most common processes and phenomena in a language. It is determined by intra and extra linguistic factors. The word is the lexical and semantic subsystem, which is more open to this process, and it is also the lexical unit, which is borrowed more easily and faster. This is prominent even in the borrowings of Albanian language from Greek. Borrowings enter a language in different ways and forms, and at different times. They are the indicators that the nations, which have developed linguistic exchanges, have had common boarders or have had historic, economic or cultural relations among them. This fact has also conditioned even the field where the Greek word or the word from any other languages has entered. It has also conditioned its lifespan and other changes that might have occurred in its form and content while being used in Albanian.

A language lexis develops and evolves continuously. This is the same even for the Albanian language lexis. It was and still is processed and enriched progressively in correspondence with the requests of the country and of the Albanian society. Albanian lexical and semantic subsystem has involved and is open to words and expressions created recently, or even to borrowings, as soon as they are required by the language agreement in society.

After having entered a language, the borrowings become subject to the grammar laws as well as the word formation of the intaking language. Almost all the Greek borrowings in Albanian (of the general and terminology lexis, the early and recent Greek borrowings, the borrowings that belong to Albanian or the dialect borrowings, the written and conversational discourse borrowings, etc.) have created word formation paradigmatic groups including derivations, compound words, conversions, etc.

Let's consider the adjective clean, the following words have derived from:

- $\quad$ with a prefix: papastër (i, e);

- $\quad$ with suffixation: pastri, pastërti, pastëror, pastroj;

- $\quad$ with compounding: zemërpastër, shpirtpastër, gjakpastër;

- $\quad$ with conversion: zemërpastërt-i (noun)2

${ }^{1}$ R. Hudson, Sociolinguistika, Tiranë, 2002, f. 94

2 Fjalor i gjuhës shqipe, Tiranë, 2006 
Pastrohem, pastrim, pastrues, pastruese, i pastruar, etc. derive from the (non-simple) front verb pastroj.

Not only do these words preserve their structure, the minimal word-formation root: i pastër, but each of them creates the respective semantic structure, the seme (the semantic components) contains, which are directly connected to a meaning, to several meanings or to the entire lexical structure of the adjective.

Albanian has borrowed even idiomatic units due to the historical and geographical relations between Albanian and Greek language. Obviously, the idiomatic units are born just like the word, they are used during spoken and written speech to fulfill the requirements and the necessities that the society has towards the language as a means of communication. They have their own distinguished features in every language. Furthermore, they reveal the national character of the lexical and semantic richness of the language more prominently and more directly than all the other lexical groups. However, we should mention the fact that the borrowing of the idiomatic units from Greek is not at the same levels as the word borrowing. For instance: a. from Greek mythology: pastroj ahuret (stallat) e Augjias), filli i Arianës, flet nga maja e Olimpit, si gosti në Olimp pëlhura e Penelopës, kutia e Pandorës, zjarri i Prometeut, bashka e artë, shpata e Damokleut, thembra e Akilit, kalë Troje, midis Skillës dhe Karibdës, dhurata e danajve, feneri i Diogjenit, fuçia e Diogjenit, feneri i Diogjenit, mundimet e Tantalit, frutat e Tantalit, guri i Sizifit, kompleksi i Edipit, fluturimi i Ikarit, nyja gordiane, kaloj Akerontin, ka veshët e Midasit, kthehem në Itakë, mollë sherri, kapërceu shtyllat e Herkulit etj.

b. with a biblical source: gjykimi i Solomonit, si Shën Thomai mosbesues, gomari i Balamit, molla e Adamit, mollë e ndaluar, pesha e kryqit, udha kryqit, toka e premtuar, arka e Noes, ardhja e dytë, ka humbur biblën, gjethe fiku, si kopshti e Edenit, qengji i Perëndisë, etc.

c. deriving from philosophy, literature, etc.: nga alfa te omega, alfa dhe omega, fluturim pindarik, dashuri platonike, ironi sokratike, gjithçka rrjedh, i thur ditirambe, kohë e artë etj.

The borrowings in Albanian language might be full borrowings, when the word has entered the way it is in Greek (there are hundreds of cases like this one in Albanian language) and structural borrowings, when the word is actually Albanian, but it is constructed according to the respective word in Greek. These structural borrowings are called calques. Calques are basically created in Albanian language; only the formation of the word is foreign in them. For example ortografi / drejtshkrim, ortoepi / drejtshqiptim, ortogonal / drejtkëndësh, etc.

Word borrowing from Greek in Albanian language was made under some certain circumstances and, as we have noticed, during some certain periods of time. The most significant kind of borrowings is the one when the word enters our language along with the concept as historic-cultural borrowings. However, Albanian language has borrowed even Greek words, which result to be language borrowings ${ }^{3}$, for some concepts it already had some other words in use.

Some of the Greek borrowings in Albanian language are: kallám, qefull, manastir, potír poganik, poganiqe, fron, thron, gjini, gjiri, qefili, perovol, avlli, tagar (mangall), gaforre, llukanik, trëndafil, dhjozmë (mendër), dafinë, skile (dhelpër), skifter, gjeraqinë, tipar, i pastër, stoli, stolis, benevrekë, farmakos (helmoj); feks (shkëlqen); gremis (rrëzoj); honeps (pëlqej); katandis (çoj në pikë të hallit); kolis (ngjis); kopanis (rrah rrobat me kopan kur i laj); kumbis, kumbisem (mbështes trupin ose kokën); lips, lipsem (më duhet); llahtaris (tmerroj); llogaris (numëroj, kontrolloj me mend); nanuris (vë në gjumë foshnjën duke i kënduar); ormis (ndreq, gatit, rregulloj); pleks (ngatërroj); psonis (blej); qëndis (qëndis diçka); skalis (gdhend, punoj me daltë gurin); sos (i jap fund diçkaje); stolis (zbukuroj); tendos (shtrij); tiganis (skuq në tigan); tromaks (frikësoj) etc. These borrowings generally belong to the general and grammar lexis, they belong to the main lexical-grammar classes such as nouns, adjectives, verbs, adverbs, etc.

Both Albanian and Greek languages are part of the Indo-European languages. This means that lots of words from Albanian fundamental fund have been inherited from its mother, Illyrian, and the latter from a language it derived from. This word fund is very stable and it is possible that every word might display all the values that characterize it. However, some borrowings from Greek, even from the modern Greek, might set aside the old Albanian word for stylistic uses, etc. This is the case of the Albanian word agër and the borrowed word from Greek gomar. The latter has created new words in Albanian language (such as: gomár, gomárez, gomarazi, gomáre, gomaria gomaricë, gomarísht, gomarjár, gomárth etc.) and tens of idiomatic units (above 30 ones)4.

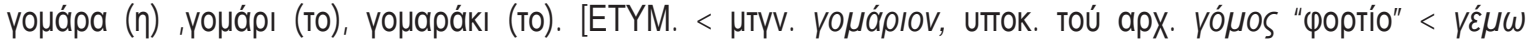

\footnotetext{
${ }^{3}$ Prof. J. Thomai writes that "the most common and widely spread lexical borrowing in Albanian language is the borrowing of the words along with the new objects or concepts. If an unknown object or concept is introduced to us, then its nomination enters the lexis according to the language it comes from. So, words such as bankë, buletin, sonet... are borrowed from Italian; basketboll, boks, gol, volejboll ... are borrowed from English, etc. These are historic-cultural borrowings. The language borrowings occur when the borrowed words do not enter along with the new concepts, but they are used as synonyms along with the words of the country where they are applied." Refer to J. Thomai, Leksikologji e gjuhës shqipe, Tiranë, 2008, pg. 272

${ }_{4}^{4}$ Fjalor i gjuhës shqipe, Tiranë, 2006
} 


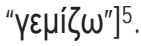

These interferences of the general lexis have occurred over the centuries even when Albanian language, unlike Greek, was not processed in all its subsystems. Borrowing happened even because Albanian language did not have an explanatory dictionary that could summarize and codify its lexical and semantic richness in order to accomplish its main function: being informative. This situation is not the same nowadays, because the circumstances are completely different and Albanian language is closed towards them. For example: the word gajdhur (gomar, agër) is used in the variant of the dialect, but the processed and codified standard Albanian language does not raise to the level of the norm this contemporary lexical borrowing (as in the case of the word pras - presh, etc.).

According to some researchers, foreign words enrich the language, but according to some other ones they spoil it. The Greek borrowings, which belong to history and not to modern days, such as: lakër, mokër, i pastër, murg etc. are positioned in the contemporary Albanian language lexis because they are used based on the values they have brought, such as; signing, semantic, word-formation, expressive, stylistic values, etc. In the awareness of the young user, they are not treated as unnecessary borrowings, but as Albanian language fortune. The word-formation, semantic, paradigmatic, stylistic developments and even other ones, which have happened to them, show their validity. They have become a part of the Albanian language lexis and their replacement with other words cannot happen anymore.

However, there are even words that should be avoided, particularly the ones that live along with the Albanian word, which have become parts of the dialects or of the social communications (this is noticed among the Albanian emigrants in Greece). The issue of the lexis purity is directly connected with the protection of the mother tongue, as the main feature of nationality, from any foreign interventions, as well as with the crystallization of the standard language norms in the lexis. In this system, the literary norm is more flexible than in phonetics and grammar. This means that except for some lexical variants (such as synonyms), the standard language accepts even foreign words, which are necessary for their content and for the requirements of some fields, such as terminology, the scientific discourse, etc. However, the unlimited rush of the foreign words is unacceptable. This phenomenon occurred in the last decade of the XX century and is still continuing nowadays, particularly in journalism and in the political-social area. Considerable selecting and adapting work should be done in this aspect, because journalism has an irreplaceable part in the general and linguistic background of the people, particularly of the young generation.

Prof. E. Çabej specifies that cleaning the foreign body from the language is a scientific and a national obligation. It is not a sign of chauvinism at all, because chauvinism is not in the traditions of the Albanians. The most classical example regarding the enrichment and the protection of the mother tongue word is shown by the Greek language itself, which is very hesitant towards the unnecessary words, even though different styles face the Greek word with the unnecessary English, French, German, Russian, etc. word.

The ways and the means to deal with the cleaning against borrowings (even though we should not fight against every foreign word in Albanian) exist. Even the opportunities and the people exist. Social and national responsibility and work are necessary. Prof. Miço Samara explains that "Based on our research, it was found that the main way to enrich the political-social lexis with new units is even their formation according to the morphological way; i.e. the formation of the words or of the terms with Albanian bases, according to its formation ways and types, or their creation through calquing (particularly for some terms), in accordance even with the requirements to clean it from the unnecessary borrowings. The new formation of this lexis, according to this approach, are generally knowledge words (of the field of political and social sciences and of the book discourse) $)^{6}$.

Let's refer to some lexical and semantic interferences we should be critical with, in order to replace them, but always in a scientific and unbiased way, without falling into purism: cukunidhe (hithër), cukunis (më djeg hithri, më përcëllon, por edhe më shndërrime kuptimore të figurshme), psonis (bëj pazar, blej), llagar (i pastër, i kulluar), llagaros (pastroj, kulloj), dhokan (zdrukth), dhokanis (e lodh, e mërzit), patom (shputa e këmbës: Sa ma ka patomën!), potis (ujit), potistir (ujitëse lulesh etj.), foti (kandil, ndriçues me vajguri), kallafatis (ha, përpij), skordhan (tarator), kalistir (vegël me presë e me veshë për të prashitur), suflaqe (pite etj. të mbushura me mish, qepë, domate, salcë etj.), proftas (arrij: nuk proftasa - nuk arrita...), palikar (trim), vromë (i pistë, grua e përdalë), skupje (fshesë), skupidhe (të fshirat, mbeturina), qinito (celular), merokamë (ditëpunë) etc.

Nowadays, Albanian language has increased the contacts with Greek language for several reasons, among which we could mention the fact that about 600,000 Albanians work in Greece as economy emigrants. They are facing a

${ }^{5}$ G. Babiniotis, Lexiko tis Neas Ellinikis Glossas, me scholia gia ti sosti chrisi ton lexeon, ermineutiko, etymologiko, orthografiko, synonimon-antitheton, kyrion onomaton, epistimonikon oron, akronymion, me axiopiesi, tou glossikou archeiou, Athine: Kentro Lexikologias e.p.e., 2002, pg. 432

${ }^{6}$ M. Samara, Pasurimi i leksikut politiko-shoqëror me njësi të reja në shqipen e sotme, në SF, 3-4, 2008 
situation of bilingualism with Albanian as the language of their heart and Greek as the language of bread. Lots of Greek words are found in the lexis of these Albanian speakers, such as: qinito, endaksi, signomi, efaristo, gjiro, psomi, nero, paidhaqe, buzuqi etc., which are unfortunately used even in Albania, where the situation of bilingualism does not exist. Continuous work is necessary in order for the Albanians to preserve their own language, but even to avoid the entrance of the unnecessary words (such as qinito, afendiko, merokamë, lefta etc.).

Borrowing has got its own enriching value, but limitless borrowing without a control and a boarder, becomes a damaging phenomenon for our language, particularly when the spoken speech or the lexical layer of the general use are conquered by foreign words. Therefore, efforts should be made to prevent borrowing words from other languages or to exclude the foreign words when their equivalents exist in Albanian and are more popular, correct and clear for the Albanian speaker. The wide activity of the writers, journalists, of the political and social representatives, of the people of art and culture, etc. should become concrete by replacing the unnecessary parasitic foreign words with Albanian words to clean and to enrich the standard language.

\section{References}

R. Hudson, Sociolinguistika, Tiranë, 2002

J. Thomai, Leksikologji e gjuhës shqipe, Tiranë, 2008 Fjalor i gjuhës shqipe, Tiranë, 2006

M. Samara, Pasurimi i leksikut politiko-shoqëror me njësi të reja në shqipen e sotme, në SF, 3-4, 2008

Gj. Shkurtaj, Sociolinguistikë e shqipes, Tiranë 2003, f. 312

G. Babiniotis, Lexiko tis Neas Ellinikis Glossas, me scholia gia ti sosti chrisi ton lexeon, ermineutiko, etymologiko, orthografiko, synonimon-antitheton, kyrion onomaton, epistimonikon oron, akronymion, me axiopiesi, tou glossikou archeiou, Athine: Kentro Lexikologias e.p.e., 2002 